\begin{tabular}{|c|c|c|}
\hline 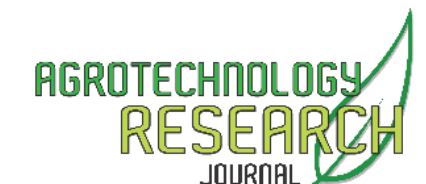 & $\begin{array}{c}\text { Agrotech Res J, December 2019, 3(2):103-106 } \\
\text { AGROTECHNOLOGY RESEARCH } \\
\text { JOURNAL }\end{array}$ & $\begin{array}{l}\text { ISSN 2655-7924 (Print) } \\
\text { ISSN 2614-7416 (Online) } \\
\text { https://jurnal.uns.ac.id/arj } \\
\text { doi: } 10.20961 / \text { agrotechresj.v3i2.33866 }\end{array}$ \\
\hline
\end{tabular}

\title{
Selection and Formulation of Endophytic Bacteria as Plant Resistance Elicitor against Wilt Disease of Tomato
}

\author{
Arika Purnawati $^{1^{*}}$, Wiwik Harjani ${ }^{2}$, Herry Nirwanto ${ }^{3}$ \\ ${ }^{1-3}$ Department of Agrotechnology, Faculty of Agriculture, Universitas Pembangunan Nasional "Veteran", Surabaya, \\ Indonesia
}

${ }^{*}$ Corresponding Author:

E-mail: arika_p@upnjatim.ac.id

Received 14 August 2019; Accepted 28 October 2019; Published 30 December 2019

\begin{abstract}
Wilt disease of Solanaceae caused by Ralstonia solanacearum reduce the crop quality and negatively affect the crop product. The objective of this research was to discover of endophytic bacteria formulation that effectively decreases bacterial which cause wilt disease on Solanaceae. The research consisted of purification of Ralstonia solanacearum, endophytic bacteria were obtained from the sample and the screening of endophytic bacteria using this following assay: antagonist assay, seedling assay and in planta assay. The results showed that in antagonist assay, the bacterial isolate code $\mathrm{PS}_{1}, \mathrm{PS}_{2}$, and $\mathrm{PS}_{8}$ could inhibit growth of $R$. solanacearum. From the seedling assay, it obtained that all of the isolates increased of percentage of germination, seed coating and powder formulation can decrease disease incidence of bacterial wilt disease.
\end{abstract}

(C) 2019 Agrotechnology Research Journal

Keywords: Biocontrol; Endophytic bacteria; Ralstonia solanacearum; Wilt disease

Cite This As: Purnawati A, Harjani W, Nirwanto H. 2019. Selection and Formulation of Endophytic Bacteria as Plant Resistance Elicitor Against Wilt Disease of Tomato. Agrotech Res J 3(2): 103-106. https://doi.org/10.20961/agrotechresj.v3i2.33866

\section{INTRODUCTION}

Ralstonia solanacearum triggers wilt disease of Solanaceae plant, reducing the crop quality and downgrade the agriculture economic impact. Farmers have controlled the disease using several methods including cultivation techniques, physical treatment, and the application of resistant varieties, bactericide, and antibiotics, however, it seems important to find the alternative way using biocontrol (Yuliar et al. 2015). Biocontrol using biology agents was investigated. Several endophytic bacteria have been explored for biocontrol agents for the disease. The mechanism for biocontrol is bacterial metabolites affect the plant to increase the resistance to pathogens and elicites induced systemic resistance (ISR). Kloepper and Ryu (2007) reported that ISR is elicited by rhizobacteria or other nonpathogenic microorganisms.

Endophytic bacteria are a group of microbes that live in plant tissue, without plant disease and related plants in mutualism symbiosis. Endophytic bacteria is in healthy tissues such as seeds, roots, stems, and leaves. Plant take benefit from the presence of

This is an open access article

Licensed under the Creative Commons Attribution International License CC-BY-SA 4.0 endophytic bacteria because it produces compounds or secondary metabolites and antibiotics that stimulate growth hormone to affect plant growth and increases plant resistance to pathogens (Bandara et al. 2006). Endophytic bacteria can be isolated from the roots, stems, flowers, and cotyledons, the space between cells in a tissue or vessel (Athman 2006) and its effectiveness depend on formulation.

The objective of this research was to discover endophytic bacteria isolated from tomato stems and root and investigate their potential as biocontrol agents against tomato bacterial wilt disease.

\section{MATERIALS AND METHODS}

\section{Suspension of $\boldsymbol{R}$. solanacearum}

$R$. solanacearum that used for the research was a personal collection of Dr. Arika Purnawati then was purified in Nutrient Agar (NA) medium for 24 hours incubation. One loopful purified isolate was taken and homogenized with $10 \mathrm{ml}$ sterile distilled water.

\section{Isolation of endophytic bacteria Isolation from tomato stem}

Endophytic bacteria were isolated from healthy tomato stem varieties Permata ( 3 months old). The stem with $50 \mathrm{~cm}$ long from the base was washed with water to clean the surface then the parts were cut into $1 \mathrm{~cm}$ long. The specimen was sterilized using $\mathrm{NaOCl}$ $1.25 \%$ for 1 minute, dyed absolute alcohol for $5 \mathrm{sec}$ and 
did 3 times, dipped into sterile water for 5 sec (repeat 3 times), dried on sterile filter paper in laminar airflow (LAF) for 5 minutes.

Specimen was splited into two parts and inoculated on PDA medium (Difco): $39 \mathrm{~g} / \mathrm{L}, \mathrm{pH} 7.0$ in a sterile Petri dish with position of inner surface touch medium or tummy position then was incubated in an incubator at room temperature $\left(28^{\circ} \mathrm{C}\right)$ for 48 hours. The growing endophytic bacteria was indicated by are milky white colonies and shiny surface on Petri dish. The isolate was inoculated on sterile NA medium (Difco): $8 \mathrm{~g} / \mathrm{L}$, $\mathrm{pH} 7.0$ for bacteria to obtained pure cultures.

\section{Isolation from tomato root}

All plant parts of the tomato roots were washed with water to clean the surface then the parts were cut into $1 \mathrm{~cm}$ long. The specimen was sterilized using $\mathrm{NaOCl}$ $1.25 \%$ for 1 minute, dyed absolute alcohol for $5 \mathrm{sec}$ (repeat 3 times), dipped into sterile water then the specimen was dried on sterile filter paper in laminar airflow (LAF) for 5 minutes.

The specimen was inoculated on PDA medium an upright position on the medium so the pieces touch the bottom of the medium then was incubated in an incubator at room temperature $\left(28^{\circ} \mathrm{C}\right)$ for 48 hours. Milky white colonies and shiny surface form on the top of growth media indicating that bacteria grow successfully. Then bacteria inoculated on NA medium for bacteria to obtained pure cultures.

\section{Formulations}

\section{Seed coating}

Healthy tomato seeds varieties Permata were sterilized with $1 \% \mathrm{NaOCl}$ for 30 seconds then rinsed with sterile water 3 times and dried on sterile tissue paper. The seed was coated using talk then immersed in a suspension of endophytic bacteria $\left(10^{8} \mathrm{CFU} / \mathrm{mL}\right)$ for 30 seconds.

The suspension was made by adding $10 \mathrm{~mL}$ sterile water into pure isolate and homogenized. The seed was sowed on soil media, after 30 days old seedlings was transferred to polybag that have been filled soil media for a further experiment (Purnawati et al. 2014).

\section{Dry powder}

Ten gram of Methylcelulosa (MC) then added $40 \mathrm{~g}$ of talk and $15 \mathrm{~g}$ of $\mathrm{CaCO}$, all three were mixed until homogeneous, sterilized for 0 minutes with autoclave. The suspension of endophytic bacteria $\left(10^{8} \mathrm{CFU} / \mathrm{mL}\right)$ was made by adding $10 \mathrm{~mL}$ sterile water into pure isolate and homogenized. Suspension with 24 hours old was taken $400 \mathrm{~mL}$ and then inoculated into the bacterial carrier mixture. The awaited treatment for 20 minutes then stored at $25 \pm 2^{\circ} \mathrm{C}$ for $3-4$ days until dry to obtain powder form (Purnawati et al. 2014).

\section{Antagonist assay}

This assay used seed coating method. Healthy seeds were sterilized with $1 \% \mathrm{NaOCl}$ for 30 seconds then rinsed with sterile water 3 times and dried on sterile tissue paper. Sterile seeds were soaked in suspension of endophytic bacteria $\left(10^{8} \mathrm{cfu} / \mathrm{ml}\right)$ for 30 and 60 seconds then planted in NA media and incubated for 24 hours at $28^{\circ} \mathrm{C}, 0.2 \mathrm{~mL}$ of suspension R. solanacearum $\left(10^{8} \mathrm{CFU} / \mathrm{mL}\right)$ mixed with $6 \mathrm{ml}$ of
$0.6 \%$ WA and poured on to the seed surface. The treatment was incubated for 24 hours at $28^{\circ} \mathrm{C}$. The observed variable was the clear zone around the seed at 24, 48, 72 hours (Purnawati et al. 2014).

\section{Seedling assay}

The assay using for seed coating formulation. The soil was mixed with compost (1:1). The soil was sterilized using $5 \%$ formalin then covered with plastic for 7 days. The soil was dried for 7 days then put into the tray and ready to be used to germinate seeds. Tomato seeds were soaked with suspension endophytic bacteria $\mathrm{PS}_{1}, \mathrm{PS}_{2}$, and $\mathrm{PS}_{8}\left(10^{8} \mathrm{CFU} / \mathrm{mL}\right)$ then sowing in a tray, for control seeds were soaked in sterile water then sowing in a tray. Indicator observation is the percentage of germination (Purnawati et al. 2014).

\section{In planta assay}

Effectiveness assay in vivo was conducted in a greenhouse used seed coat and powder formulation. $R$. solanacearum $\left(10^{8} \mathrm{cfu} / \mathrm{ml}\right)$ was inoculated into soil using poured technique. Seed coat formulation was planted into soiland wait until the plants are grown. Indicator observation were incubation period and disease incidence during 60 days.

\section{Data analysis}

The data of clear zone size and disease incidence of wilt disease were statistically analyzed using analysis of variance (ANOVA) and Least Significant Difference (LSD) $5 \%$.

\section{RESULT AND DISCUSSION \\ Antagonist assay}

The results of antagonist assay, isolates $\mathrm{PS}_{1}, \mathrm{PS}_{2}$, and $\mathrm{PS}_{8}$ at 30 seconds and at all observation time can inhibit the growth of $R$. solanacearum. in general, the size of the clear zones formed by $\mathrm{PS}_{1}$ and $\mathrm{PS}_{2}$ were greater than that formed by $\mathrm{PS}_{8}$ (Table 1). This was because both of them produced phenol and siderophores compounds that it can adhere to the surface of the seed coat that was semipermeable so when used for antagonist assay was able to form clear zone.

Table 1. Clear zone size at antagonist assay

\begin{tabular}{lccc}
\hline \multirow{2}{*}{ Treatments } & \multicolumn{3}{c}{ Time observation (h) } \\
\cline { 2 - 4 } & 24 & 48 & 72 \\
\hline $\mathrm{PS}_{1}$ & $3 \mathrm{a}$ & $5.2 \mathrm{a}$ & $7 \mathrm{a}$ \\
$\mathrm{PS}_{2}$ & $3 \mathrm{a}$ & $5.2 \mathrm{a}$ & $7 \mathrm{a}$ \\
$\mathrm{PS}_{8}$ & $2 \mathrm{a}$ & $4.5 \mathrm{a}$ & $5 \mathrm{a}$ \\
LSD 5\% & 0.25 & 0.82 & 2.15 \\
\hline
\end{tabular}

Zhou et al. (2013) reported that tomato seed coat was semipermiable and composed of fat, pectin, and cellulose, this was evidenced by coloring techniques and histochemical analysis. It is due to phenol and siderophores compounds in seeds indicated that the molecules of these compounds are chemically bound to fat molecules, pectin, cellulose so that when used to assay antagonism it was able to form a bright zone. 
Siderofor is a compound composed of hydroxamic molecules and catechol can be attached to the seed coat composed of fat, pectin, and cellulose. Besides, phenol and siderophores compounds produced by endophytic bacteria are thought to have a molecular size smaller than fat and protein so that they are capable of diffusing and adhering to the surface of the tomato seed coat.

\section{Seedling assay}

Percentage germination $\mathrm{PS}_{1}$ and $\mathrm{PS}_{2}$ was higher than $\mathrm{PS}_{8}$, but all of them increase percentage germination Table 2 likewise for the length of sprout $\mathrm{PS}_{1}$ and $\mathrm{PS}_{2}$ was longer than $\mathrm{PS}_{8}$, but all of them increase the length of sprout (Table 3).

It was because the seeds produced siderophores that influenced the activity of the gibberellic acid to stimulate seed germination and break down seed dormancy. They also produced gibberellic acid that affected the concentration of gibberellin acid in the seeds. Gibberellic acid naturally in the seeds contained in aleuron and when the seeds are covered with a whisk of endophytic bacteria.

Table 2. Percentage of germination (\%)

\begin{tabular}{lllll}
\hline \multirow{2}{*}{ Treatments } & \multicolumn{4}{c}{ Time observation (days) } \\
\cline { 2 - 5 } & 14 & 21 & 28 & 35 \\
\hline $\mathrm{C}$ & 60 & 60 & 60 & 60 \\
$\mathrm{PS}_{1}$ & 80 & 80 & 90 & 90 \\
$\mathrm{PS}_{2}$ & 80 & 80 & 90 & 90 \\
$\mathrm{PS}_{8}$ & 65 & 75 & 75 & 75 \\
\hline
\end{tabular}

Table 3. Length of sprout $(\mathrm{cm})$

\begin{tabular}{lllll}
\hline \multirow{2}{*}{ Treatments } & \multicolumn{4}{c}{ Time observation (days) } \\
\cline { 2 - 5 } & 14 & 21 & 28 & 35 \\
\hline $\mathrm{C}$ & 20 & 20 & 20 & 25 \\
$\mathrm{PS}_{1}$ & 45 & 45 & 45 & 50 \\
$\mathrm{PS}_{2}$ & 45 & 45 & 45 & 50 \\
$\mathrm{PS}_{8}$ & 35 & 35 & 35 & 40 \\
\hline
\end{tabular}

Endophytic bacteria beaten into the aleurone seeds so the concentration of gibberellic acid increases. Seed germination generally begins with the imbibition of water in the seeds, then the gibberellic acid activity will break dormancy and stimulate germination. Patel et al. (2012) reported that endophytic bacteria Pseudomonas aeruginosa isolated from tomato plants in Gujarat were able to produce siderophore and gibberellic acid growth hormone which affected seed germination, as well as research conducted by Umamaheswari et al. (2013), reported that endophytic bacteria Bacillus sp., Micrococcus sp., Pseudomonas sp., Flavobacterium sp. and Serratia sp. from tropical legume produced gibberellin acid that affects the seed vigor index.
Yamaguchi (2008) reported that gibberellin acid was a group of growth hormone in plants that had a function as a seed germination stimulator and elongation of sprouts also according to Waqas et al. (2012) that soybean seeds soaked in endophytic microbial filtrate caused an increase in gibberellin acid content so that the percentage of seed sprout power and vigor index were increased. Research conducted by Arwiyanto and Simbolon (2009) reported that the tobacco seeds covered by Pseudomonas putida up to the age of 40 days after transplanting can increase the tobacco vigor index and not phytotoxic.

\section{In planta assay}

Results of in planta assay, the incubation period of wilt disease for $\mathrm{PS}_{1}$ and $\mathrm{PS}_{2}$ is 16 days, $\mathrm{PS}_{8}$ is 14 days. Seed coating formulation for $\mathrm{PS}_{1}, \mathrm{PS}_{2}, \mathrm{PS}_{8}$ can reduce wilt disease incidence and higher than powder formulation (Table 4 and 5). So there was no difference for each isolate at each formulation except to control. This was because the seeds produced phenol and siderophores compounds that it can adhere to the surface of the seed coat that was semipermeable and bound to the seed coat that induces systemic plant resistance. Zhou et al. (2013) reported that tomato seed coat was semipermeable and composed of fat, pectin, and cellulose, this was evidenced by coloring techniques and histochemical analysis because phenol and siderophores compounds in seeds indicate that the molecules of these compounds are chemically bound to fat molecules, pectin, cellulose. Moreover, another reason is that phenol and siderophore that bind to the seed elicit resistance gen of solanaceae plants against $R$. solanacearum and effectiveness of inducing systemic plant resistance.

The effectiveness of biological control using biocontrol agent can be enhanced through the application of different techniques like soaking the roots or seeds before transplanting and resulting in the more rapid induction of resistance (Junaid et al. 2013). Otherwise, development of the disease is influenced by the environment are temperature was $34^{\circ} \mathrm{C}$, humidity is $80 \%$. Fajinmi and Fajinmi (2010) reported that temperature supports the development the wilt disease was $25-35^{\circ} \mathrm{C}$ with $86 \%$ humidity, so Purnawati and Nirwanto (2015) reported that the incubation period $R$. solanacearum on potato varieties was $6.5-21.3$ days.

Research has conducted by Purnawati et al. (2014) proved that application of endophytic bacteria will affect phenol activity in plants so that plants were more resistant to pathogenic bacteria $R$. solanacearum. Phenol compounds in plants will be produced as a reaction of plants to the presence of pathogenic infections and generally an increase in phenol concentration will accumulate on the pathogen infection site causing barriers to pathogen activity and the results of phenol analysis on plants showed that in tomatoes inoculated $R$. solanacearum $148,613 \pm 1,734$ ppm. 
Table 4. Disease incidence (dry powder)

\begin{tabular}{lccccccc}
\hline \multirow{2}{*}{ Treatments } & \multicolumn{7}{c}{ Time observation (days) } \\
\cline { 2 - 8 } & 14 & 21 & 28 & 35 & 42 & 49 & 56 \\
\hline $\mathrm{C}$ & $3.51 \mathrm{a}$ & $13.5 \mathrm{a}$ & $13.5 \mathrm{a}$ & $18.11 \mathrm{a}$ & $18.11 \mathrm{a}$ & $18.11 \mathrm{a}$ & $18.11 \mathrm{a}$ \\
$\mathrm{PS}_{1}$ & $0.15 \mathrm{~b}$ & $3.75 \mathrm{~b}$ & $3.75 \mathrm{~b}$ & $7.5 \mathrm{~b}$ & $7.5 \mathrm{~b}$ & $7.5 \mathrm{~b}$ & $10.25 \mathrm{~b}$ \\
$\mathrm{PS}_{2}$ & $0.15 \mathrm{~b}$ & $3.75 \mathrm{~b}$ & $3.75 \mathrm{~b}$ & $7.5 \mathrm{~b}$ & $7.5 \mathrm{~b}$ & $7.5 \mathrm{~b}$ & $10.25 \mathrm{~b}$ \\
$\mathrm{PS}_{8}$ & $0.15 \mathrm{~b}$ & $5.23 \mathrm{~b}$ & $5.23 \mathrm{~b}$ & $8.75 \mathrm{~b}$ & $8.75 \mathrm{~b}$ & $8.75 \mathrm{~b}$ & $9.5 \mathrm{~b}$ \\
$\mathrm{LSD} \%$ & 3.36 & 1.51 & 1.51 & 1.8 & 1.8 & 1.8 & 1.9 \\
\hline
\end{tabular}

Table 5. Disease incidence (seed coating)

\begin{tabular}{lccccccc}
\hline \multirow{2}{*}{ Treatments } & \multicolumn{7}{c}{ Time observation (days) } \\
\cline { 2 - 8 } & 14 & 21 & 28 & 35 & 42 & 49 & 56 \\
\hline $\mathrm{C}$ & $3.51 \mathrm{a}$ & $13.5 \mathrm{a}$ & $13.5 \mathrm{a}$ & $18.11 \mathrm{a}$ & $18.11 \mathrm{a}$ & $18.11 \mathrm{a}$ & $18.11 \mathrm{a}$ \\
$\mathrm{PS}_{1}$ & $0.15 \mathrm{~b}$ & $3.75 \mathrm{~b}$ & $3.75 \mathrm{~b}$ & $6 \mathrm{~b}$ & $6 \mathrm{~b}$ & $6 \mathrm{~b}$ & $6 \mathrm{~b}$ \\
$\mathrm{PS}_{2}$ & $0.15 \mathrm{~b}$ & $3.75 \mathrm{~b}$ & $3.75 \mathrm{~b}$ & $6 \mathrm{~b}$ & $6 \mathrm{~b}$ & $6 \mathrm{~b}$ & $6 \mathrm{~b}$ \\
$\mathrm{PS}$ & $0.15 \mathrm{~b}$ & $5.23 \mathrm{~b}$ & $5.23 \mathrm{~b}$ & $7.5 \mathrm{~b}$ & $7.5 \mathrm{~b}$ & $7.5 \mathrm{~b}$ & $7.5 \mathrm{~b}$ \\
$\mathrm{LSD} \mathrm{5 \%}$ & 3.36 & 1.51 & 1.51 & 1.75 & 1.75 & 1.75 & 0.5 \\
\hline
\end{tabular}

\section{CONCLUSION}

Isolates of endophytic bacteria coded PS ${ }_{1}, \mathrm{PS}_{2}, \mathrm{PS}_{8}$ in antagonist assay could inhibit growth of $R$. solanacearum, in seedling assay inducing germination, increasing sprout length, and not toxic, in planta assay using formulation seed coating and dry powder they can decrease of wilt disease and elicited of resistance tomato plant to wilt disease.

\section{REFERENCES}

Arwiyanto T, Simbolon FM. 2009. Biological Control of Solanaceous Plant Bacterial Wilt by Seed Coating. In: XVII International Conference on Bioencapsulation; 2009 September 24-26; Groningen, Netherlands. p. 24-26.

Athman SY. 2006. Review of The Role of Endophytes in Biological Control of Plant-parasitic Nematodes with Special Reference to The Banana Nematode, Radopholus similis (Cobb) Thorne. Thesis. Pretoria: University of Pretoria.

Bandara WM, Seneviratne G, Kulasooriya SA. 2006. Interactions Among Endophytes and Fungi: Effects and Potentials. J Biosci. 31(5): 645-650.

Fajinmi AA, Fajinmi OB. 2010. An Overview of Bacterial Wilt Disease of Tomato in Nigeria. Agric J. 5: 242-247.

Junaid JM, Dar NA, Bhat TA, Hussain BA, Bhat, MA. 2013. Commercial Biocontrol Agents and Their Mechanism of Action in the Management of Plant Pathogens. Int J Mod Plant Anim. Sci. 1: 39-57.

Kloepper JW, Ryu CM. 2006. Bacterial Endophytes as Elicitors of Induced Systemic Resistance. In: Schulz
BJE, Boyle CJC, Sieber TN, editors. Microbial Root Endophytes. Soil Biology 9. Berlin: Springer.

Maheswari TU, Anbukkarasi K, Hemalatha T, Chendrayan K. 2013. Studies on Phytohormone Producing Ability of indigenous Endophytic Bacteria Isolated from Tropical Legume Crops. Int J Curr Microbiol App Sci. 2(6): 127-136.

Patel H, Patel RK, Khristi SM, Parikh K, Rajendran G. 2012. Isolation and Characterization of Bacterial Endophytes From Lycopersicon Esculentum. Nepal J Biotechnol. 2(1): 37-52.

Purnawati A, Sastrahidayat IR, Abadi AL, Hadiastono T. 2014. Endophytic Bacteria as Biocontrol Agents of Tomato Bacterial Wilt Disease. J Trop Life Sci. 4(1): 33-36.

Purnawati A, Nirwanto H. 2015. Biocontrol of Wilt Disease on Pepper Using Endophytic Bacteria in Malang Indonesia. J Biol Agric Healthc. 5(13): 100-102.

Waqas M, Khan AL, Hamayun M, Kamran M, Kang S, Kim Y, Lee I. 2012. Assessment of Endophytic Fungi Cultural Filtrate on Soybean Seed Germination. African J. 11(85): 15135-15143.

Yamaguchi S. 2008. Gibberellin Metabolism and its Regulation. Annu Rev Plant Biol. 59: 225-251.

Yuliar, Nion YA, Toyota K. 2015. Recent Trends in Control Methods for Bacterial Wilt Diseases Caused by Ralstonia solanacearum. Microbes Environ. 30(1): 1-11.

Zhou J, Wang Y, Jahufer Z. 2013. Location and Chemical Composition of Semi-Permeable Layer of Forage Seeds. Bangladesh J Bot. 42(1): 23-30. 